\title{
Scleredema Diabeticorum in a Patient with the Normal Range of the Hemoglobin A1c Level and Impaired Glucose Tolerance
}

\author{
Hiromasa Matsuda $^{1}$, Naoki Oiso ${ }^{1 *}$, Yukie Fujita $^{2}$, Hiroshi Ikegami ${ }^{2}$, Akira Kawada ${ }^{1}$ \\ ${ }^{1}$ Departments of Dermatology, Kinki University Faculty of Medicine, Osaka, Japan; ${ }^{2}$ Departments of Endocrinology, Metabolism \\ and Diabetes, Kinki University Faculty of Medicine, Osaka, Japan. \\ Email: "naoiso@med.kindai.ac.jp
}

Received May $7^{\text {th }}, 2012$; revised June $13^{\text {th }}, 2012$; accepted June $28^{\text {th }}, 2012$

\begin{abstract}
Scleredema diabeticorum is an uncommon skin disorder showing a diffuse, symmetrical, and non-pitting persistent induration developing initially on the nape. It usually occurs in patients with poorly controlled or insulin-resistant diabetes mellitus. We present a 57-year-old woman with scleredema diabeticorum with hemoglobin A1c 6.1\% (normal, 4.7\% $6.2 \%$ ) and impaired glucose tolerance. Alcian blue staining at $\mathrm{pH} 7.0$ illustrated deposits of acid mucopolysaccharides between the collagen bundles in the reticular dermis, but the staining at $\mathrm{pH} 1.5 \mathrm{did}$ not show the deposits. This case indicates that scleredema diabeticorum may be an early indicator of undiagnosed diabetes mellitus in some cases, and that impaired glucose tolerance test should be performed for individuals with scleredema even though the hemoglobin A1c level is within the normal range.
\end{abstract}

Keywords: Scleredema Diabeticorum; Alcian Blue Staining; Diabetes Mellitus; Hemoglobin A1c; Impaired Glucose Tolerance; An Early Indicator

\section{Introduction}

Scleredema diabeticorum, a rare disorder of unknown etiology, is characterized by a diffuse, symmetrical, and nonpitting persistent induration of the skin [1]. It first appears on the nape of the neck and then on the shoulders and back. It is commonly preceded by long-existing, poorly controlled diabetes mellitus [1]. Here, we present a 57year-old woman with scleredema diabeticorum associated with impaired glucose tolerance.

\section{Case Report}

A 57-year-old woman visited us with a slowly developing asymptomatic eruption on the nape. She had first noticed it three months earlier. A physical examination revealed the presence of an ill-defined, non-pitting, induration on the nape (Figure 1). She had not been diagnosed as having diabetes. She had no recent episode of infectious disorders. Laboratory blood test results were hemoglobin A1c (HbAlc): $6.1 \%$ (normal, 4.7\% - 6.2\%); total cholesterol: $228 \mathrm{mg} / \mathrm{dl}$; triglyceride: $122 \mathrm{mg} / \mathrm{dl}$; highdensity-lipoprotein cholesterol: $51 \mathrm{mg} / \mathrm{dl}$; anti-hepatitis B surface antibody: negative; anti-hepatitis $\mathrm{C}$ virus antibody:

"Corresponding author. negative; anti-human immunodeficiency virus type I (HIV-I) antibody: negative; and anti-HIV-II antibody: negative. We did not examine the laboratory blood test for paraproteinemia, hyperparathyroidism and connective tissue diseases. A biopsy specimen revealed a thickened dermis with mucinous change (Figures 2(a) and (b)). Alcian blue staining at $\mathrm{pH} 7.0$ showed deposits of acid mucopolysaccharides between the collagen bundles in

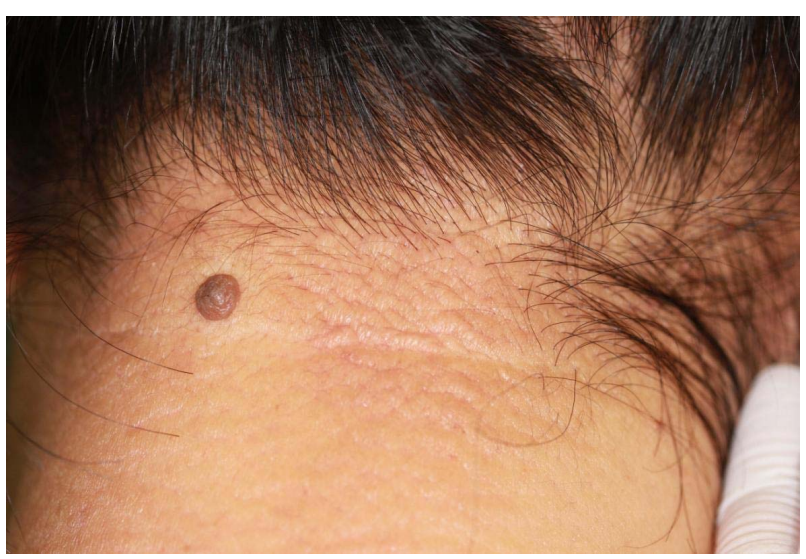

Figure 1. Clinical appearance of the nape of the neck at the first visit. 


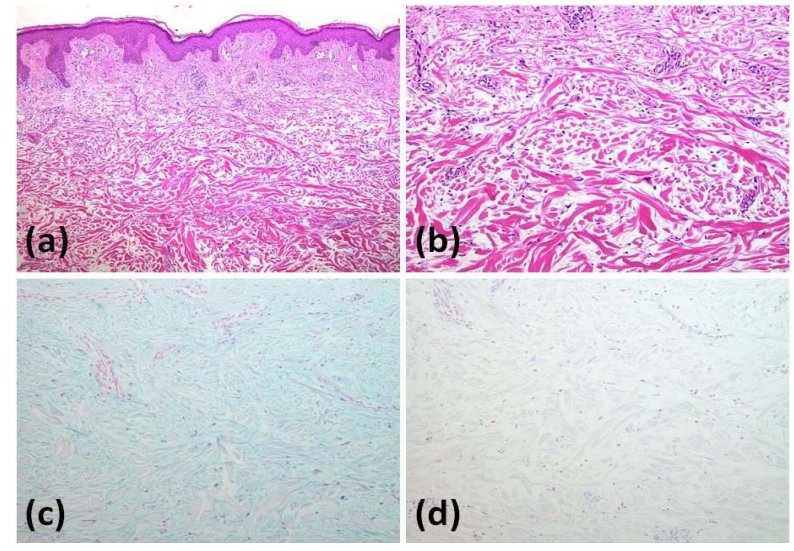

Figure 2. (a) and (b) A biopsy specimen from the affected nape (hematoxylin and eosin stain, original magnification, (a) $\times 40$; (b) $\times 100$ ); (c) A specimen stained with alcian blue at $\mathbf{p H} 7.0$ (original magnification, $\times 100$ ); (d) A specimen stained with alcian blue at pH 1.5 (original magnification, $\times 100)$.

the reticular dermis (Figure 2(c)). Alcian blue staining at pH 1.5 did not show deposits (Figure 2(d)). A $75 \mathrm{~g}$ oral glucose tolerance test (OGTT) was performed to examine the serum glucose, serum immunoreactive insulin (IRI), and serum C-peptide immunoreactivity (CPR) (Table 1).

We recommended exercising, such as walking, for an hour per day and eating a nutritionally balanced diet. Three months later, the induration regressed and flattened (Figure 3). The patient did not wish to undergo an OGTT after regression.

\section{Discussion}

Scleredema is caused by deposits of only nonsulfated acid mucopolysaccharides, which alcian blue stains at $\mathrm{pH}$ 7.0 but not at $\mathrm{pH}$ 1.5. Scleredema has two main types: Scleredema adultorum of Buschke and scleredema diabeticorum [2]. Buschke-type scleredema is commonly recognized as a post-inflammatory, sudden-onset subtype that generally regresses within a few weeks to months. The lack of a recent infectious episode, noted at a first medical examination, suggests that the eruption was a nonBuschke-type. Even though the HbAlc level was within the normal range, we performed an OGTT and identified impaired glucose tolerance. The eruption was diagnosed with scleredema diabeticorum associated with impaired glucose tolerance.

Patients with diabetes mellitus may develop a skin disorder that is an early indicator of undiagnosed or a complication of known diabetes mellitus [3]. Cutaneous signs include scleredema diabeticorum, lichen planus, acanthosis nigricans, disseminated granuloma annulare, necrobiosis lipoideca, eruptive xanthomas and others. Nigam et al. reported that $30.3 \%$ patients with lichen
Table 1. Results of $75 \mathrm{~g}$ oral glucose tolerance test.

\begin{tabular}{cccccc}
\hline Time $(\mathrm{min})$ & 0 & 30 & 60 & 90 & 120 \\
\hline Serum glucose $(\mathrm{mg} / \mathrm{dl})$ & 101 & 147 & 168 & 179 & 150 \\
$\mathrm{IRI}(\mu \mathrm{U} / \mathrm{ml})$ & 8.1 & 57.0 & 44.1 & 61.8 & 57.4 \\
$\mathrm{CPR}(\mathrm{ng} / \mathrm{ml})$ & 1.37 & 6.22 & 6.33 & 8.21 & 9.59 \\
\hline
\end{tabular}

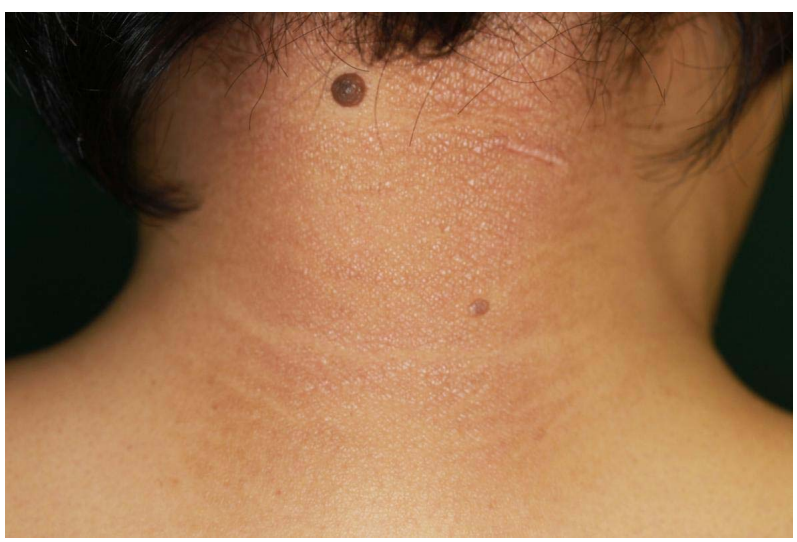

Figure 3. Clinical appearance of the nape of the neck three months later from the first visit.

planus showed abnormal glucose tolerance [4]. Scleredema diabeticorum is a relatively underestimated complication of diabetes $[5,6]$. It had been debated whether scleredema adultorum of Buschke and scleredema diabeticorum are identical disease [7], because the condition of scleredema diabeticorum is believed to be essentially permanent. Meguerditchian et al. suggested that scleredema of Buschke or scleredema diabetorum is a skin complication of diabetes and that type 1 or type 2 diabetes may be associated with the condition in more than $50 \%$ of cases [6]. Our case would be an instance of scleredema diabetorum as a reversible early indicator of diabetes.

As shown here, scleredema diabeticorum may be one of an early indicator of undiagnosed diabetes mellitus. We hypothesize that regression of scleredema diabeticorum in this case may be associated with disappearance of impaired glucose tolerance as a result of increased physical activity and a nutritionally balanced diet. Patients having scleredema on the nape is recommended to undergo an OGTT even if the HbAlc level is within the normal range.

\section{REFERENCES}

[1] N. Thumpimukvatana, C. Wongpraparut and H. W. Lim, "Scleredema Diabeticorum Successfully Treated with U1traviolet A1 Phototherapy," Journal of Dermatolgy, Vol. 37, No. 12, 2010, pp. 1036-1039. doi:10.1111/j.1346-8138.2010.01014.x 

and Impaired Glucose Tolerance

[2] F. Breuckmann, C. Appelhans, A. Harati, S. Rotterdam, P. Altmeyer and A. Kreuter, "Failure of Low-Dose Methotrexate in the Treatment of Scleredema Diabeticorum in Seven Cases," Dermatology, Vol. 211, No. 3, 2005, pp. 299-301. doi:10.1159/000087031

[3] R. S. Gilgor and G. S. Lazarus, "Skin Manifestations of Diabetes Mellitus," In: H. Rifkin and P. Raskin, Eds., Diabetes Mellitus, Brady Company, Bowie, 1981, pp. 313321.

[4] P. K. Nigam, L. Sharma, J. K. Agrawal, G. Singh and S. K. Khurana, "Glucose Tolerance Studies in Lichen Planus," Dermatologica, Vol. 175, No. 6, 1987, pp. 284-289. doi:10.1159/000248835
[5] M. M. Seyger, F. H. van den Hoogen, S. de Mare, U. van Haelst and E. M. de Jong, "A Patient with a Severe Scleroedema Diabeticorum, Partially Responding to Low-Dose Methotrexate," Dermatology, Vol. 198, No. 2, 1999, pp. 177-179. doi:10.1159/000018103

[6] C. Meguerditchian, P. Jacquet, S. Béliard, T. Benderitter, R. Valéro, F. Carsuzza and B. Vialettes, "Scleredema Adultorum of Buschke: An under Recognized Skin Complication of Diabetes," Diabetes \& Metabolism, Vol. 32, No. 5, 2006, pp. 481-484.

[7] A. Krakowski, J. Covo and C. Berlin, "Diabetic Scleredema ," Dermatologica, Vol. 146, No. 3, 1973, pp. 193-198. doi: $10.1159 / 000251956$ 